\title{
血管造影描出不能肝細胞癌の組織学的特徵
}

\author{
九州大学第 2 外科, 同放射線科* \\ 調 憲 園田 孝志 松股 孝 竹中 賢治 \\ 兼松 隆之 杉町 圭蔵安森弘太郎* 増田 康治*

\section{PATHOLOGICAL EXAMINATION OF ANGIOGRAPHICALLY UNDETECTED HEPATOCELLULAR CARCINOMA} \\ Ken SHIRABE, Takashi SONODA, Takashi MATSUMATA, \\ Kenji TAKENAKA, Takashi KANEMATSU, Keizo SUGIMACHI, \\ Kotaro YASUMORI* and Kouji MASUDA* \\ Second Department of Surgery, Kyushu University, Faculty of Medicine \\ *Department of Radiology, Kyushu University, Faculty of Medicine \\ 腹部血管造影で描出不能の比較的小さな肝細胞癌が増加している。その組織学的な性格を明らかに \\ するために以下の検討を行った。対象は術前化学療法が施行されず, 切除標本での最大径 $3 \mathrm{~cm}$ 以下の \\ 肝細胞癌22例，25結節。血管造影で腫演が描出されたもの，20結節 $(80 \%)$ ，描出されなかったものは \\ 5 結節 $(20 \%)$ であった。以下，陽性，陰性結節を各項目で比較した。陽性，陰性結節おのおの，(1) \\ 被膜形成15/20 (77.5\%)，0/5 ( p <0.01)。(2)腫煌内門脈路 $3 / 20(15 \%), 5 / 5(100 \%)(\mathrm{p}<0.01)$. (3) \\ 免疫組織化学的に陰性結節の類洞様血管腔を証明した。肝動脈造影描出不能例は被膜形成がなく, 腫 \\ 瘍内に門脈路を認め, 類洞様構造を有する置換型発育を示す特徵を有していた.
}

索引用語：腹部血管造影陰性肝細胞癌，置換型発育，畽湟内門脈路

I.はじめに

超音波断層法の発達により, 小肝癌が高率に発見さ れるよらになった。 それに伴い, 超音波断層法で結節 像を認めるにもかかわらず血管造影でとら兄られない 小細胞癌が増えつつあり，小肝癌の治療方針決定にお いて問題となっている゙”.これらの血管造影にてとら 兄られない小肝癌の性格を明らかにするため, 血管造 影陽性結節, 陰性結節を組織学的に比較検討したので 報告する。

\section{II. 対象および方法}

総肝動脈より末梢の選択的肝動脈造影が導入された 昭和56年 12 月以降の血管造影陰性結節は 5 結節であっ た. 5 結節すべて最大径 $3 \mathrm{~cm}$ 以下であったため, 最大 径 $3 \mathrm{~cm}$ 以下の肝細胞癌にて血管造影陽性結節, 陰性結 節の比較検討を行った。

$<1989$ 年 5 月 8 日受理 $>$ 別刷請求先：調 憲

T812 福岡市東区馬出 $3-1-1$ 九州大学医学部 第 2 外科
対象は，昭和56年12月より昭和63年 4 月に教室にて 切除された径 $3 \mathrm{~cm}$ 以下の小肝細胞癌に抢いて総肝動 脈より末梢の選択的肝動脈造影が可能であり，かつ術 前化学療法を施行しなかった22症例, 25結節とした。 症例は年龄36 75歳, 平均 59.8 歳で, 男女比 $20 ： 2$ であった，19例が単発例， 3 例が多発例，多発例の結 節数はいずれも 2 個であった。全例肝疾患歴があり， 組織学的な肝硬変合併率は血管造影陽性結節15/ $20(75 \%)$ ，陰性結節5/5 (100\%) と有意差はなかった。 腫瘍の部位は肝左葉 6 結節 (24\%), 肝右葉 19 結節 （76\%)であった。血管造影陽性 20 結節中 3 結節は左葉 外側区域， 2 結節は内側区域に，また，12結節は右葉 前区域， 3 結節は後区域であった。血管造影陰性結節 5 結節中 4 結節は右葉前上区域， 1 結節は左葉外側区 域であった。

腹部血管造影は大駺動脈よりの Seldinger 法2)で行 われた. $16 \sim 60 \mathrm{ml}$ の76\%methylglucamine diatr izoate または iopamidol 370を使用し, 平均注入速度 


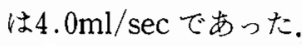

症例はすべて超音波断層法・コンピューター断層撮

影 (computed tomography；CT) を施行された.

組織学的検索は腫瘍の最大割面のへマトキシリン= エオシンン染色 (hematoxylin-eosin stain; H \& E 染色) を行い, 細胞異型度・被膜形成・隔壁形成・壊死巣 ・ WHOKよる組織分類 ${ }^{3)}$ - 発育型・睡瘍内の門脈路 （portal triad）の有無について検索を行った。壊死率 は最大割面の壊死面積より算定した。細胞異型度は Edmondson-Steiner 分類にしたがった4).さらに免度 組織化学的に血管造影陰性結節における腫汮内類洞様 構造の内皮細胞の存在を証明した。内皮細胞の第V四因 子関連抗原 (factor VIII related antigen, FVIII RAG) を酵素抗体法 (Avidin-Biotin-Peroxidase Complex; ABC 法)を用いて染色した. FVIII RAG染色は $\mathrm{DAKO}$ 社製 $\mathrm{ABC}$ キットを用い, 発色剂は $3,3^{\prime}$ 。 diaminobenzidine (DAB) を使用した。

な拉，有意差検定には Chi-square test と Student's

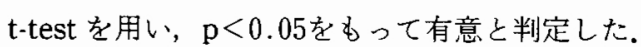

\section{III. 結 果}

\section{1. 選択的肝動脈造影像}

選択的肝動脈造影上，腫瘍濃染像・新生血管像など の陽性所見を認めたもの $20 / 25(80 \%)$ ，所見を認めな かったもの $5 / 25(20 \%)$ で，検出率は $80 \%$ であった。 陰性 5 結節中 1 結節は, 総肝動脈造影では描出されな かったのに右肝動脈造影で新生血管像と腫瘍濃染像を 認めた。(本研究では総肝動脈造影を基準としているの で陰性群に含めた。)

\section{2. 腫湟径}

平均腫瘍径は血管造影陽性結節 $2.0 \pm 0.6$, 陰性結節 $1.7 \pm 0.4 \mathrm{~cm}$ であり，陰性結節の方が小さい傾向はあ るものの, 有意差はなかった(表 1)。をた，陰性結節 の最大腫瘍径は $2.2 \mathrm{~cm}$ であった。

\section{3. 細胞異型度}

細胞異型度を Edmondson-Steiner 分類でみてみる と, 陽性結節 I 型 0 , II 型17/20 (85\%), III 型3/ 20 (15\%), IV型 0 。陰性結節 I 型 $3 / 5(60 \%)$, II 型 $2 /$ 5 (40\%), III型 0 , IV型 0 と陰性結節に高分化型の肝 癌が多い傾向を認めた。

4. 被膜形成

被膜形成は陽性例で15/20(75\%), 陰性例で0/ $5(0 \%)$ と有意に陰性結節に非被包型の肝癌が多かっ た $(\mathrm{p}<0.01)$ (表 1 ).

\section{5. 隔壁形成}

表 1 血管造影

\begin{tabular}{|c|c|c|c|}
\hline & $\begin{array}{l}\text { 陽性結節 } \\
(\mathrm{n}=20)\end{array}$ & $\begin{array}{l}\text { 陰性結節 } \\
(\mathrm{n}=5)\end{array}$ & $\mathrm{P}$ \\
\hline 腫瘍径. & $2.0 \pm 0.6$ & $1.7 \pm 0.4$ & NS \\
\hline 被膜形战 & $15 / 20(75 \%)$ & 0 & $\mathrm{p}<0.01$ \\
\hline 隔壁形成 & $13 / 20(65 \%)$ & 0 & $\mathrm{p}<0.01$ \\
\hline 置換型発青 & $320: 15 \%$ & $5 / 5(100 \%)$ & $\mathrm{p}<0.01$ \\
\hline 睡檩内伐脈路 & $320: 15 \%$ & $5 / 5 \quad 100 \%)$ & $\mathrm{p}<0.01$ \\
\hline
\end{tabular}

図 1 小肝癌の置換性発育を示す，基本的な肝小葉の 線維格子網は保たれている。矢印は癌部一非癌部の 境界を示す.（H＆Ｅ染色, ×140)

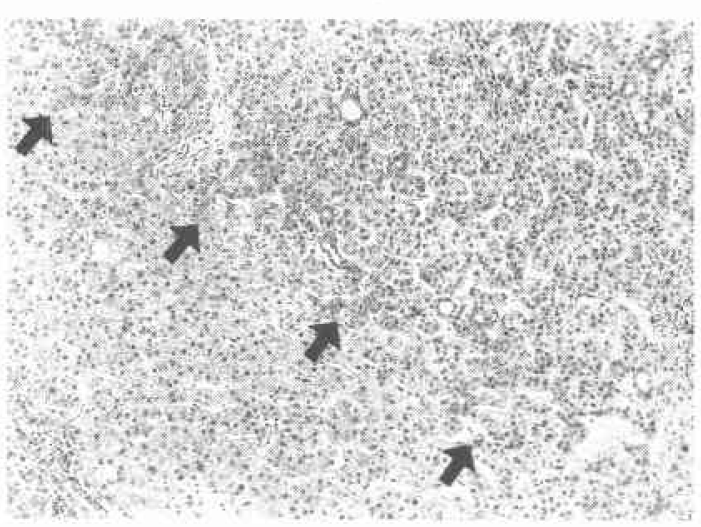

隔壁は陽性結節 $13 / 20(65 \%) ，$ 陰性結節 $0 / 5$ で有意差 を持って高頻度に陽性例に形成を認めた（p<0.01） (表 1 ).

\section{6 . 壊死栄}

肝動脈造影陽性結節では 2 結節（10\%）に25\%以下 の自然壊死を認めたのに対し，陰性結節では壊死を認 めなかった。

\section{WHO による組織分類}

WHO の組織分類で比較すると，陽性結節では trabecular type $15 / 20$ (75\%), pseudoglandular type $1 / 20$ ( $5 \%$ ), compact type $3 / 20(15 \%)$, scirrhous type $1 / 20(5 \%)$, 陰性結節 trabecular type $3 /$ $5(60 \%)$, pseudoglandular type $2 / 5(40 \%)$, compact type 0 , scirrhous type 0であり, 陰性結節に pseudoglandular type が多い傾向を認めた。 また，陰性結節の 索状構造をとっている部分は thin trabecularであり， 類洞様血管腔はよく発達していた。

8. 発育型

癌細胞が肝細胞索に沿ってあたか子正常肝細胞と置 き変わるように増殖し, 基本的な肝小葉の格子線維網 
図 2 腫瘍実質内の門脈路を示す. 畽瘍のほぼ中心に 位置し，胆管・動脈・門脈を有している。（H＆E染 色, $\times 96$ )

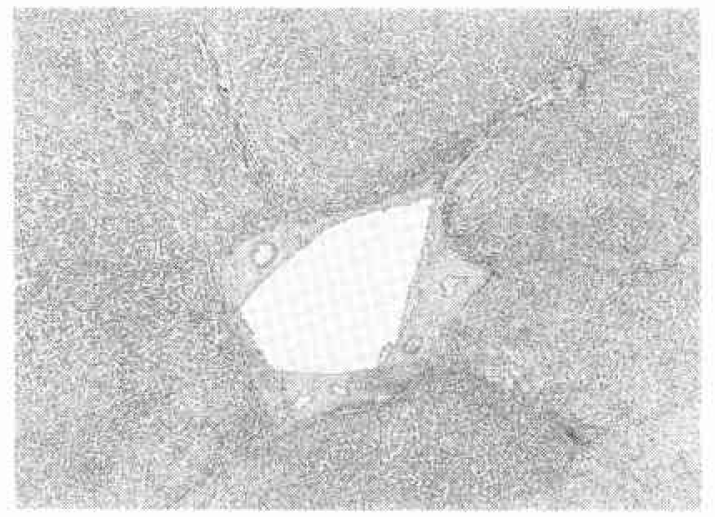

図 3 血管造影陰性結節の内皮細胞の第VII関連抗原 （FVIII RAG）を酵素抗体法で免疫組織化学的に染 色した。矢印のように紡錘形の核を有する内皮細胞 が, 類洞様構造を形成している(FVIII RAG 染色, メ 560)

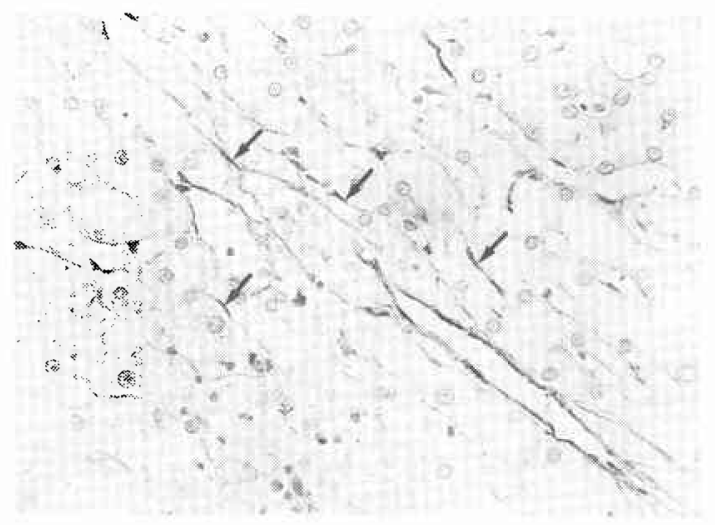

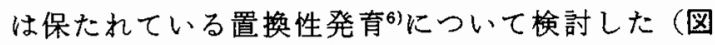
1). 25 結節中 8 結節， $32 \%$ に置換性の発育を認めた。 血管造影所見別の出現頻度を比較検討すると，陽性結 節3/20 (15\%)，陰性結節5/5（100\%）と有意に陰性結 節に置換性発育を示すものを多く認めた（ $\mathrm{p}<0.01 ）$

(表 1).

\section{9. 腫瘍内門脈路}

腫瘍実質内の胆管・動脈・門脈を有する門脈路（portal triad）の有無について比較検討した（図 2 ）。腫瘍 内門脈路は，血管造影陽性結節3/20(15\%), 陰性結節 $5 / 5(100 \%)$ と有意に陰性結節に腫疸内門脈路を多く 認めた $(p<0.01)$.
10. 腫瘍内類洞様構造の内皮細胞（血管造影陰性結 節について)

血管造影陰性結節について類洞様構造の内皮細胞の 存在を免疫組織化学的に証明した，腫澔内の内皮細胞 は非癌部に比べて小型で抗原性もやや弱い傾向がある ものの，発達した類洞様構造を裏打らするように存在 していた（図 3 ).

\section{IV. 考察}

選択的肝動脈造影法にて描出されない小肝細胞癌を 組織学的に検討すると，被膜・隔壁形成を認めず，腫 瘍境界部では置換性の発育形式を示す高分化な癌細胞 より構成されており，乙かも全例腫瘍内に門脈路を有 していた(表 1 )。ささらに陰性結節全例に類洞様血管腔 を認めた。

これらの点は小肝細胞癌の血管構築を考皇る点で興 味深い、従来, 肝細胞癌は肝動脈支配であり，門脈分 枝は周囲に圧排・伸展されるとされてきた がら，われわれの血管造影陰性結節では，腫瘍実質内 の門脈路の存在から, 正常の 2 重血管支配が保たれて いる可能性がある。このことは血管造影における陰性 所見と密接に関連している，すなわち，血管造影陰性 であった要因を検討すると，まず，高分化で血管新生 に比較的乏しい可能性があること，さらに腫瘍実質内 に存在する門脈路を介した門脈血流により新生血管内 の造影剤が希釈され，あるいはdrainage veinとして の門脈の遺残により，血管造影上，周囲の肝組織と contrastがえられないと考劣られる。よって，われわ れの症例のごとく，より選択的に造影を行うことに よって，あるいは微細な血管の造影が可能とされる

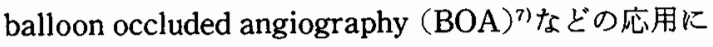
より描出される可能性がある。一方, 腫瘍内の壊死や 線維化が hypovascular な要因となることが報告され

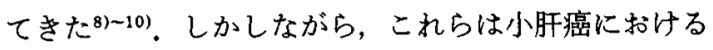
血管造影陰珄結節に必ずしもあてはまるすのではな い. Okuda $5^{11)}$ は，充実型の肝癌で間質の血管腔が之 しいものは hypovascular に, 血管腔が豊富なものは hypervascular に造影されるのであろうとしている。 さらに末永 ${ }^{12)}$, 西森ら ${ }^{13)}$ は類洞様血管腔がほとんと認 められない hypovascularな肝細胞癌を報告してい る.これらはいずれる癌細胞が著明に密集しており類 洞様血管構造が認められなかったとしているが，われ われの症例では腫瘍内の類洞様構造に内皮細胞が認め られ，類洞様血管腔の存在が証明された。よって，血 管内皮細胞が認められない，いわゆる“hypovascular 
HCC”とはその機序が異なるものと思われる，さらに われわれの報告した腫瘍は壊死がなく、これは逆に腫 瘍への血流の豊富さを示唆するものであろう。

Takayasu $5^{14)}$ は, 陰性結節は陽性結節に比べて腫 第径が小さく，高分化なものが多いとしているが，そ れらは非被包型で置換型発育を示したわれわれの小肝 癌の特徵に重なる点である。

\section{V.まとめ}

外科切除の対象となる小肝癌で, 血管造影描出不能 例はまれなものではなく，いずれる置換型発育を示し た. 病理学的見地から置換型発育はしばしばとりあげ られてきたものの，必ずしも臨床的な意義づけは明ら かではなかった，今回のわれわれの組織学的な検討に より，肝動脈・門脈系の二重支配が示唆され，その血 管構築の特殊性が示された。さらに発達した類洞様血 管腔の存在から，血管造影陰性例にも新生血管がない わけではなく、より選択的に造影することにより，あ るいは balloon occluded angiographyなどの応用に より描出される可能性が示唆された。

\section{文献}

1) 打田日出男, 大石 元：画像猃断5, X 線䛦断 (血 管造影法). 䇅田敏次 監修, 臨床肝癌 3 , 講談社, 東京, p66-93, 1988

2) Seldinger SI: Catheter replacement of the needle in percutaneous angiography A new technique. Acta Radiol 39:368-379, 1953

3) Gibson JB, Sobin LH : Histological typing of tumors of the liver, Biliary tract and pancreas. International Histological Classification of Tumors. No. 20, World Health Organization, Genova, 1978

4) Edmondson HA: Benign epithelial tumor and tumor like lesions of the liver. Edited by Okuda
K, Peters RL. Wiley Medical, New York, 1976, p309-330

5) Nakashima $T$, Kojiro $M$, Kawano $Y$ et al: Histological growth pattern of hepatocellular carcinoma. Relationship to orcein (hepatitis B surface antigen) positive cells in cancer tissue. Hum Pathol 13:563-568, 1982

6) Nakashima $T$, Kojiro $M$ : Angioarchitecture of hepatocellular carcinoma. Ed by Nakamura T, Kojiro M, In: Hepatocellular Carcinoma. An atlas of its pathology. Springer-Verlag, Tokyo, 1986, p105-115

7) 高島澄夫, 中塚春樹, 中村健治汪か：肝細胞癌に対 する新しい血管造影法一balloon occluded hepatic angiography. 日医放線会誌 $44-565-576$ ， 1986

8）奥平雅彦，佐々木憲一，中 英男ほか：覀性腫瘍の 血管構築. 脈管学 19:229-232，1979

9）佐々木憲一, 奥平雅彦: 肝癌の血管構築. 内科 Mook 18:20-29, 1982

10）木戸長一郎, 守 亮之：原発性肝癌の血管造影. 胃 と腸 11：1591-1603，1976

11) Okuda K, Obata H, Jinnouchi S et al: Angiographic assessment of gross anatomy of angiograms and liver pathology in 100 cases. Rediology 123:21-29, 1977

12）末永昌宏, 场澤增雅, 中尾昭公ほか：画像診断の解 離した多中心性発育の原発性肝細胞癌症例の検 討. 肝臓 $27: 802-809,1986$

13）西森武雄, 西野裕二, 金義哲渒加: Hypovascular な肝細胞癌の 1 例。肝臓 $29: 690-694$, 1988

14) Takayasu K, Shima $Y$, Muramastu $Y$ et al: Angiography of small hepatocellular car. cinomas : Analysis of 105 resected tumors. AJR $147: 525-529,1986$ 